\title{
The Role of Indonesian Worship Songs at Rise Up Generation (RG) Ministry Church in Tanjong Malim-Malaysia
}

\author{
${ }^{1}$ Junita Batubara, ${ }^{2}$ Kamaluddin Galingging \\ ${ }^{1}$ Music Department, Faculty of Language and Arts, \\ University HKBP Nommensen \\ nitabtbara72@gmail.com
}

\begin{abstract}
In 1928, the Borneo Evangelical Mission (BEM) in Australia established a Protestant school of religion called the Borneo Gospel Assembly Church (SIB) in Malaysia. SIB began to develop in the Sarawak and Sabah regions. Rise Up Generation (RG) ministry is one part of SIB. The songs or songs used in the worship service at RG Ministry use Indonesian worship pop songs, which is outside the custom of liturgical songs following the SIB. The author is interested in answering the question: do Indonesian worship pop songs respond to the needs of the congregation where they affect the emotions and behavior of the congregation in the RG ministry? To answer this question, the author has conducted field research using quantitative and qualitative research methods. To obtain relevant data, the authors made questionnaires and in-depth interviews with pastors and administrators of RG ministry churches where the church administrators were $100 \%$ students of the Sultan Idris Education University (UPSI). This finding shows positive signs that the songs sung in worship services meet the needs of the congregation by singing Indonesian worship pop songs. The songs were also proven to positively influence the emotions and behavior of the congregation to be more expressive in performing praise and worship. Significant influence is evident from the worship service which is held every week, namely the congregation is able to sing well. Through Indonesian worship pop songs, congregations are helped to express their faith physically and mentally by singing in worship services.
\end{abstract}

Keywords: Rise Up Generation (RG), Indonesian Popular Worship Songs, The Role of Music in Worship, Emotion and Behavior, Quantitative Approaches and Qualities in music analysis

\section{Introduction}

Rise Up Generation Church or often called RG is a part of the Malaysian Worship Assembly (SIB) Malaysia. SIB was founded by the Borneo Evangelical Mission (BEM) which had been established in Australia in 1928. His missionary pioneers came to Sarawak in late 1928 to evangelize the tribes in the heart of Borneo that had not yet been reached by the Christian faith. Realizing that they would face competition in the cities, BEM concentrated on the interior and settled near the coastal area of Murut (Lun Bawang). In 1937, the work was extended to Sabah (later known as British North Borneo). The Sarawak border area was affected by American missionaries in Kalimantan (which became known as Dutch Borneo) and most of the 
Lun Bawang group became Christians through interactions with their infidels and converts on the other side of the international boundary. This church historical process is quite long which makes the organizational structure different from other SIB churches. The organizational structure is led by pastors and their administrators are students who are active in church and committed to RG. Another difference is the atmosphere of worship. The worship procedure used is still the same as the SIB worship code but its contents are different. The contents contained in congregational songs different from SIB in general. Therefore, those differences make the writer interested to investigate further. The worship service is more specific to the worship service element (worship songs). The songs become an important element in worship because singing and praising God is the main service in church services. The church is inseparable from the songs in it. In this case, songs are a harmonious blend of lyrics and poetry which have certain meanings (Mawane, 2004). Congregational singing is an element of liturgy that is essential of worship process in church (Riemer, 1995). Songs definitely have an important role, function, and also position of worship in a church. Songs that are often sung in worship at RG are worship pop songs originated in Indonesia.

Based on Indonesian dictionary, role belongs to division or holds the leadership, focusing on occurrence of a thing or event. According to Soekanto (2012), role is a dynamic aspect of status. The difference between position and role is for knowledge. Both of them cannot be separated because they rely on each other, so the role can determine the activity and opportunities that will be given to the community or a group of people. According to Miftah Thoha (2012), a role is a series of regular behaviors that is caused by something. A role appears after someone understands that he does not work by himself and has to interact with his workplace since environment is broad, diverse, and each person will have a different environment to deal with. However, the role has no difference. Based on those definitions, the researchers were intended to investigate the role in terms of how music 'takes' the position in the Evangelical Congregation of Borneo church groups, especially in the Church Rise Up Generation (RG Ministry).

The word worship comes from the Hebrew word century which means "to serve." Then the term was extended to "worship" which means to serve, to work, and to worship. Besides, in the New Testament, the word worship is broadly understood. This is proven by the terms "lateria", "doulein" and "leiturgia" (Hursepuny, 2010). According to Abineno (1960), the term "doulein" has the meaning of working as a servant and the term "lateria" has the meaning of working to get a wage or salary. According to Lutheran in White (2005), the meaning of worship is with the recognition that nothing happens in it except the loving God speaks to humans both through His holy words, prayers, and worships.

According to Janet Goodridge (1999) in Wijayanto (2015), that musical elements occur in motion (without being limited to the understanding of general limits on rhythm), which is about rhythm and timing or timing of human movements. In his opinion, rhythm is well described as a combination in which the regularity of energy distribution, various emphasis and changes in purpose, intensity, speed, and movement (including silence). It is essential to achieve an effective result. Meanwhile, according to Djohan (2010) in Wijayanto (2015) states that tempo in music has a strong influence on melody, because the song composition must have a 
rhythm (tempo). The timbre of the musical instrument used is also needed and important to support the desired atmosphere of the song.

Furthermore, the melody of a song created is generally relatively unchanged but the tempo and timbre elements are still possible to be changed. Each element has the power to affect the feelings of its listener so that if one experiences a modification it will cause a different effect. It possibly happens regardless of how the music and the song is (Djohan (2010) in Wijayanto, 2015). In this case the musical elements are very necessary for the role of Indonesian worship songs accompanied by a musical instrument including a keyboard, guitar melody, bass guitar and a drum set. Sometimes, there are additional musical instruments depends a number of music players present, such as saxophone, violin and flute. From those descriptions, musical elements such as melody, rhythm, tempo, cadence, harmony, dynamics, and timbre have strong influence on emotional experiences when the RG Ministry congregation sings Indonesian worship songs.

\section{Problem Statement}

Based on the research, the problem was presented with two questions, namely how the role of popular worship songs from Indonesia towards the congregation is and what the benefits of worship songs for the growth of RG Ministry Tanjung Malim congregation are.

\section{Methodology}

The research method is an investigation or a system that is controlled, empirical, and critical towards phenomena in order to look for facts, new theories, hypotheses and truths by using certain steps in order to find scientific answers to a problem (Sujarweni, 2014: 3). To obtain the expected results, research methods were needed to be scientifically justified. The research method used in this study was a combination method. According to Jhonson and Cristensen (2007) in Sugiyono (2016) explains the combination method (mixed research) combines quantitative and qualitative approaches. It includes philosophical foundations, the use of qualitative and quantitative approaches and combining the two approaches in research. Population is a generalization area consisting of: objects/subjects that have certain qualities and characteristics determined by researchers to be studied and then drawn conclusions (Sugiyono, 2016). The population in this study was the entire GM group where most of congregation were UPSI students. The subject was the population of the congregation who worship at RG Ministry Tanjung Malim.

\section{Finding/Conclusion/Implication}

The results of this study were seen from quantitative and qualitative by making a questionnaire divided into 7 items namely respondent demographics, role and function of music, Indonesian pop songs, multi-media, song lieder/singer/dancer, congregational emotions, and behavior congregation. With the seven items above, it could be seen the results of the role, function and positive benefits of Indonesian worship pop songs used in devotional programs at RG Ministry. From the researcher's observations, there were a lot of popular Indonesian worship songs that were used in worship services every week by the RG Ministry congregation. For more accurate data needed by researchers, the researchers consulted Pastor David Ukong in making a list of the names of popular Indonesian worship songs that are often sung at the church. From the results of the 
consultation, 24 selected popular Indonesian worship songs were included in the questionnaire, where the aim was to see how far the congregation knew the 24 songs. The songs stated in the questionnaire are: 1) "Dia Mengerti" (He Understands); 2) "Sentuh Hatiku” (Touch My Heart); 3) "Ku di Bri Kuasa” (I was Given Power); 4) "Bangkit Serukan Nama Yesus" (Rise Up to Cry Jesus' Name); 5) "Oh Betapa Indahnya" (Oh How Beautiful); 6) "Walau Seribu Reba Disisiku" (Even though a Thousand Reba is by My Side); 7) "Bapa Yang Kekal”" (Eternal Father); 8) "Bapa Yang Setia” (Faithful Father); 9) "JanjiMU Seperti Fajar" (Your Promise Is Like Dawn); 10) "Lingkupiku" (My scope); 11) "Smua Baik" (All Good); 12) "Mengejar HadirMU" (Pursuing Your Present); 13) "Kaulah Harapan" (You're the Hope); 14) "Dalam Ku Menyembah" (In Me Worship); 15) "Segala Yang Kumiliki" (Everything I Have); 16) “Kusiapkan Hatiku Tuhan” (I Prepare My Heart, Lord); 17) “Aku Berserah" (I Surrender); 18) “Jangan Lelah Bekerja Diladangnya Tuhan” (Don't Tired of Working in God's Field); 19) "Yesus Kekasih Jiwaku” (Jesus is My Beloved); 20) "KuasaNYA Tak Berubah" (His Power will not Changed); 21) "Sbab Tuhan Baik" (From Good God); 22) "Oh Betapa Indahnya” (Oh How Beautiful); 23) "Betapa Hebat” (How Great); 24) "Kunyanyi Haleluya” (I Sing Hallelujah).

From the results of the questionnaire answered by the congregation showed that $83.12 \%$ of the congregation had/often played or sung the 24 songs above. It also can be seen that the most played song is "Sentuh Hatiku" (Touch My Heart) as $88.51 \%$, the song "Sbab Tuhan Baik" (From Good God with a value of $88.37 \%$, the song "Bangkit Serukan Nama Yesus" (Rise Up to Cry Jesus' Name) as much as $87.70 \%$ , the song "Bapa Yang Kekal" (Eternal Father) by $87.56 \%$, the song "Jangan Lelah Bekerja Diladangnya Tuhan" (Don't Tired of Working in God's Field) as much as $87.56 \%$, the song "Yesus Kekasih Jiwaku" (Jesus is My Beloved) as much as $87.56 \%$, the song "Kunyanyi Haleluya" (I Sing Hallelujah) as much as $87.43 \%$, the song "Ku di Bri Kuasa" (I was Given Power) as much as $86.62 \%$, the song "Bapa Yang Setia" (Faithful Father) as much as $86.21 \%$, the song "JanjiMU Seperti Fajar" (Your Promise Is Like Dawn) as much as $85.11 \%$, the song "Dia Mengerti" (He Understands) as much as $84.45 \%$, the song "Betapa Hebat" (Oh How Great) as much as $84.32 \%$, the song "Lingkupiku" (My scope) as much as $84.14 \%$, the song "Oh Betapa Indahnya" (Oh How Beautiful) as much as $80.27 \%$, the song "Oh Betapa Indahnya" (Oh How Beautiful) as much as $80.13 \%$, the song "Smua Baik" (All Good) as much as $80.27 \%$, the song "Mengejar HadirMU" (Pursuing Your Present) as much as $80 \%$, the song "Kusiapkan Hatiku Tuhan" (I Prepare My Heart, Lord) as much as $80 \%$, the song "Dalam Ku Menyembah" (In Me Worship) as much as $78.78 \%$, the song "Aku Berserah" (I Surrender) as much as 78.10\%, the song "Segala Yang Kumiliki" (Everything I Have ) was as much as $74.32 \%$, the song of "KuasaNYA Tak Berubah" (His Power will not Changed) as much as $73.91 \%$, and the last "Walau Seribu Reba Disisiku" (Even a Thousand Reba is by My Side) as much as 73.64. From the data, respondents' answers stated that $86.75 \%$ of Indonesian worship pop songs were always adjusted to the theme of the sermon every week.

From the researchers' observation, the form of RG Ministry church worship in a spontaneous informal style provided space for the congregation to express their emotional experiences by singing songs for worship. Music in worship services in the RG Ministry church was important in accompanying congregational singing and had an effect on the emotional experience of the congregation during worship. Music could also affect the atmosphere of worship conducted in the church. In addition, all of music 
players played an important role in helping the singing quality of the congregation. In this case, the number of music player depended on the conditions of the available musical instruments at the RG Ministry church. The instruments were a drum set, bass, melody, keyboard, and some additional musical instruments such as saxophone, violin and flute. The music was presented by four to six music players with a combo band formation. The term in musicology (West) is a small ensemble of performer as an instrumental presenter and accompanist vocalist of popular songs which consists of instruments carrying the melody, counter melody, and rhythmic regulator.

Music players always collaborate with song lieder and singers. The collaboration between them is closely related since the song lieder gives signs or cues through the movement of the hand or fingers to give a clue when the music is played. Usually, a song lieder gives a signal to repeat or stop the song. Music players are given freedom in arranging their music but they are still adjusted to the cues given by song lieder and singers. Beside song lieder and singers, there are also dancers who are always included in worship sermon. The dancers always adjust their dance movements according to the rhythm played by the musician.

In worship sermon at RG Ministry there was always a one-to-one relationship between musicians, song lieder/singers, and dancers. In this case, musicians, song lieder/singers, and dancers practiced together in church three days or two days before worship each week. It was necessary to harmonize the songs performed with the musical instruments and dances that would be performed. From the results of questionnaire regarding the role and function of music in worship in RG Ministry Church was $90.29 \%$, where the value of each item were described as follows 1) Keyboard players could clearly play the melody and chords and rhythm of the song played by $91.08 \%$, 2) Drum players could play rhythm well with by $91.76 \%, 3$ ) Bass guitar players got to play rhythm, rhythm of songs that are sung well by $91.76 \%$, 4) Melody guitar players could play melodies and melody variations with good score by $91.35 \%$, 5) Harmonization between music players went well got a score of $89.86 \%$, 6) Having codes between music players to play a song by $88.11 \%$, 7) The role of a group of musicians really helped me to sing a pop song worship Indonesia by $89.19 \%, 8$ ) There was a link between music and multi-media by $88.65 \%$, 9) In the sermon music was also played with value of $94.59 \%, 10$ ) Music was played in accordance with the original song by $90.41 \%, 11)$ Music was played with an improvisation/addition by $87.84 \%, 12$ ) There was a music link connecting with the song leader/singer/dancer by $89.59 \%$, and 13) Music players did exercise the day before the religious service took place by $89.59 \%$. From the results of the respondents above, the role and function of music in worship in the RG Ministry church was very important and musicians with song lieder/singers. Besides, dancers had an interaction relationship with each other in worship sermon every week. The results of interviews with members of the RG Ministry church congregation stated that the role of music in bringing Indonesian worship pop songs was very important to express the interpretation of the congregation who had relationship with religion and was expected to bring the atmosphere of worship as desired. Congregations, who were mostly students, they preferred Indonesian worship pop songs because they were easier to understand and were able to express themselves in services.

In addition to the role of music that helped the worship at RG Ministry, the role of Multimedia also carried an important role in worship. From the research results, it stated that $75.54 \%$ of the congregation agreed to use multimedia. The uses of 
multimedia helped congregations show the poems of songs that were sung so they sang these songs easier. The six points in the multimedia questionnaire were stated as follows: 1) The song poems that were displayed based on the order of the song lyrics was $80.27 \%$, 2) I memorized the song and did not need multimedia with a value of $63.78 \%, 3$ ) I did not memorize songs so I needed multimedia with a value of $86.78 \%$, 4) I memorized songs and it was a necessity to provide multimedia with a value of $75.54 \%, 5)$ Without multimedia, services could run well in a church by $75.54 \%$, and 6) Multimedia was very helpful in praise and worship with a value of $89.32 \%$ Furthermore, the song lieder, singer, and dancer had a close relationship in worshiping at the RG Ministry church. This could be seen from the results of the respondents about the importance of their role by $88.74 \%$. It showed that the role of song lieder/singer/dancer in the church as important as the role of music. All three supported each other. Song lieder/singer was needed to guide the congregation to sing in worship services. Song lieder are leaders of praise who is responsible for carrying out the task of leading praise well. Song Lieder was expected to lead praise in worship services. Before starting worship services, song lieder prepared a list of songs to be sung that were adapted to the theme of the sermon every week. They coordinated with Pastor David Ukong as preacher. Then, they practiced together with music players and dancers as well as multi-media officers. During the practice, lieder compiled songs based on themes and determined how many songs will be performed at the religious service. Here, the lieder/singer was ready in 30 minutes before the service starts. The time for holding the worship service usually takes place every morning at 9.30 .

The results of observations showed that Indonesian worship pop songs are used by the RG Ministry congregation in worship services on Sundays. The worship procedure was used harmony within charismatic church fellowship. In Indonesia, it included praise worship, prayer and anointing, the delivery of the word of God, offerings, then prayer and anointing, blessing and closing. One member of the RG Ministry congregation said that the reason for choosing Indonesian worship pop songs since Indonesian was easier to understand. The RG Ministry also claimed the use of Indonesian worship songs to continue service in the church. Additionally, almost $100 \%$ of the congregations were young people who were studying at UPSI and came from different denominations. The presence of young people became the limelight of Pastor David Ukong so the selection of songs was focused on Indonesian worship pop songs.

One member of the congregation who is also one of the administrators in the church said that Indonesian worship pop songs can be interpreted more by singing continuously until everyone can hear and feel the presence of God. Chanting is not just a form of expression of gratitude and praise but rather a mandate for us to do God's will. Here is an example of an Indonesian worship pop song sung at a religious service called "Touch My Heart" by Maria Shandi:

Betapa kumencintaiMu, segala yang tlah terjadi

(How much I love You, everything that has happened,)

Tak pernah sendiri, jalani hidup ini, selalu menyertai

(Never alone, live this life, always accompanying)

Betapa kumenyadari, di dalam hidupku ini

(How I realized, in my life) 
slalu memberi rancangan terbaik, oleh karena kasih

(You always give the

best design, out of

love) Chorus

Bapa, sentuh hatiku, ubah hidupku, menjadi yang baru

(Father, touch my heart, change my life, become a new one)

Bagai, emas yang murni, Kau membentuk bejana hatiku

(Like, pure gold, you formed the vessel of my heart)

Bapa, ajarku mengerti, sebuah kasih yang selalu member

(Father, my teaching understands, a love that always gives)

Bagai, air mengalir yang tiada pernah berhenti

(Like, water that never stops flowing)

This song is one of Indonesia's worship pop songs which was loved by the RG Ministry congregation. This song is not just about congregation singing and worshiping God, but the words in the song help congregation to always truly believe in God. The songs used by the church in worship were songs that the congregation like and not only sung during worship but are ingrained in the congregation's daily lives, especially in the struggle of those who wander for study and away from family. Most of the congregation said that Indonesian worship pop songs were more touching and specially made for young people to be more enthusiasts in praising God with simple and meaningful words (the results of an interview with Pastor David Ukong). Indonesian worship pop songs made the atmosphere of worship not monotonous or boring. Furthermore, simple lyrics in that song made the RG Ministry's congregation easily understand and feel God's presence (the result of an interview with Pastor David Ukong).

In the opinion of pastor David Ukong, the congregation is not only united in one fellowship but also the congregation can express their hearts and feelings through praise. SIB in general has a fixed liturgical system with songs that have their own books. But specifically at RG Ministry, it does not use the liturgical system applicable in SIB because almost all congregations are aged between 19-23 years where all congregations are students who are studying at UPSI and from different church denominations. For this reason, Pastor Jumi (as a pioneer in the opening of the SIB church branch in Tanjong Malim) took a different approach, namely by using Indonesian worship songs in worship every week. This was resumed by Pastor David Ukong. In the SIB tradition, it also does not become a problem if Indonesian worship pop songs are included in the ordinances of worship given that the church continues to move in carrying out God's mission. Lastly, it is necessary to renew aspects of service in the church.

The existence of Indonesian worship pop songs was able to influence the congregation in singing with the aim of proclaiming and carrying out the good news. The songs also gave strength to the self of the congregation, helped the congregation in the growth of faith, and expressed praise and worship. Indonesian worship pop songs also brought positive benefits to the RG Ministry congregation in a form of unity among members of the congregation as a church community in Tanjong Malim. Researchers saw that it was quite beneficial for the congregation to use worship pop songs to build relationships with God. Another 
benefit that could be seen was the congregation is more enthusiastic about performing praise and worship with their respective interpretations, and cried while praising and worshiping due to the lyrics of the song.

The churches in Malaysia, especially the Borneo Worship Congregation, had their own worship services which were always used in every church that had the same flow as the SIB. However, the RG Ministry church had special features where the worship system was like the worship service that applied in the charismatic church, namely praise worship, prayer $\&$ anointing, the delivery of the word, offerings, the blessing, and closing. In the worship service which is held every Sunday, it is always using Indonesian worship pop songs.

Indonesian worship pop songs were adapted to the theme of sermon before it was delivered. Generally, the chosen songs were adjusted to the theme ( 2 or 3 songs). After the song selection, the song lieder, singer, music player, dancer and multi-media held 2 or 1 practice before the day of worship. In this practice, the music players will adjust the rhythm to adjust the exact harmony in performing praise and worship in the church. During the practice, the discussion was about how to repeat the song, how many repetitions the song need, the hand code or fingers used to have harmony in singing and playing the music. The role of music was prioritized for religious services with the aim of helping congregants express their feelings, tell their faith, unite fellowship, and strengthen their struggle to life every day. In the importance of music role at RG Ministry church, it showed that the benefits of music were definitely connected to the development of congregation's soul in performing praise and worship. Moreover, the benefits of music could be seen from the influence of the congregation to sing, the strength of music for congregation, and the more expressive congregation in performing praise and worship.

\section{References}

Abineno, J.L. Ch. 1983. Apa kata Alkitab Jakarta: BPK Gunung Mulia.

1960. Ibadah Jemaat dalam Perjanjian Baru. Jakarta: BPK Gunung Mulia.

1966. Unsur-unsur liturgi Jakarta : PT Kinta.

Barker, Cris. 2005. Cultural studies teori dan praktik. Yogykarta: PT Bentang Pustaka. Borwnlee, Malcolm. 2008. Tugas Manusia dalam Dunia Milik Tuhan.

Dharmaputera, Eka.1999. Bergumul dalam Pengharapan (Struggling in Hope) _. Jakarta:BPK Gunung Mulia. De Jonge, Christian. 2008. Apa itu Calvinisme? Jakarta: Gunung Mulia.

Deng, Francis M.1995. War Of Visions : Conict of identities in the sudan. Wasington DC, Brooking.

Elysabeth Asrit Suyanti Lakapu. 2001. Faktor-faktor yang mempengaruhi ketidakhadiran jemaat dalam ibadah minggu menurut Majelis Jemaat di GMIT Maranatha Oebufu Kupang. (Skripsi). 
Engel J.D. 2007. Liturgika pemahaman dan penghayatan ibadah dalam liturgi gereja Salatiga: Tisara Grafika. G. Riemer. 1995. Cermin Injil. Jakarta : Litindo. 